\title{
Phosphorylated protein concentrate pumpkin seed (Cucurbita moschata): optimization by response surface methodology and nutritional characterization
}

\section{Naglezi de Menezes Lovatto ${ }^{*}$ (D) Bruno Bianchi Loureiro ${ }^{1}$ Ana Betine Beutinger Bender ${ }^{2}$ iD Cristiane Bianchi Loureiro ${ }^{3}$ Fernanda Rodrigues Goulart $^{1}$ (D) Caroline Sefrin Speroni ${ }^{2}$ Fernanda Teixeira Macagnan ${ }^{2}$ Mariana Piana ${ }^{4}$ Leila Picolli da Silva ${ }^{1}$}

\author{
${ }^{1}$ Departamento de Zootecnia, Universidade Federal de Santa Maria (UFSM), 97105-900, Santa Maria, RS, Brasil. E-mail: naglezilovatto@hotmail.com. \\ ${ }^{*}$ Corresponding author. \\ ${ }^{2}$ Departamento de Solo, Universidade Federal de Santa Maria (UFSM), Santa Maria, RS, Brasil. \\ ${ }^{3}$ Departamento de Tecnologia dos Alimentos, Universidade Federal de Santa Maria (UFSM), Santa Maria, RS, Brasil. \\ ${ }^{4}$ Departamento Farmácia Industrial, Universidade Federal de Santa Maria (UFSM), Santa Maria, RS, Brasil.
}

ABSTRACT: Response surface methodology was used to determine optimum conditions for extraction of protein from pumpkin seed meal. A central composite rotational design (CCRD) including independent variables such, pH and sodium trimetaphosphate (STMP) content was used. Maximum yield was obtained at a central point of CCRD, with STMP content and pH of 4\% and 4.5, respectively. These conditions resulted in protein yield of $50.04 \mathrm{~g}$ of soluble protein from extract $/ 100 \mathrm{~g}$ pumpkin seed. The optimization of pH and STMP content allowed

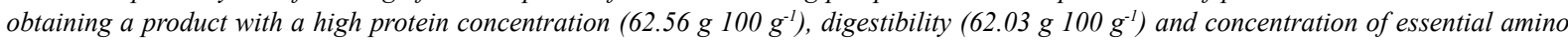
acids $\left(27.26 \mathrm{~g} 100 \mathrm{~g}^{-1}\right)$. Regarding the polyphenols concentration, phosphorylated protein concentrate from pumpkin seed and the pumpkin

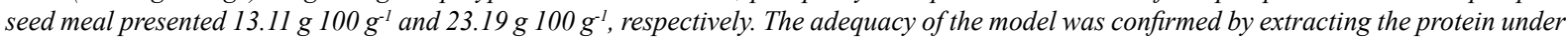
optimum values. These results help in designing the process of optimal protein extraction from pumpkin seeds.

Key words: amino acids, central composite rotational design, in vitro digestibility, new ingredient.

Concentrado proteico fosforilado de semente de abóbora (Cucurbita moschata): otimização pela metodologia de superfície resposta e caracterização nutricional

RESUMO: A metodologia de superficie resposta foi utilizada para determinar condições ideais para a extração de proteína da farinha de semente de abóbora. Foi utilizado um delineamento composto central rotacional (DCCR), incluindo vários níveis independentes, tais como pH e trimetafosfato de sódio (TMPS). O rendimento máximo foi obtido em um ponto central de DCCR, com conteúdo de TMPS e pH de 4\% e 4,5, respectivamente. Essas condições resultaram em rendimento proteico de 50,04 g de proteína solúvel no extrato/100 $\mathrm{g}$ de semente de abóbora. $\mathrm{A}$ otimização de $\mathrm{pH}$ e conteúdo de TMS permitiu a obtenção de um produto com alta concentração de proteína $\left(62,56 \mathrm{~g} 100 \mathrm{~g}^{-1}\right)$, digestibilidade

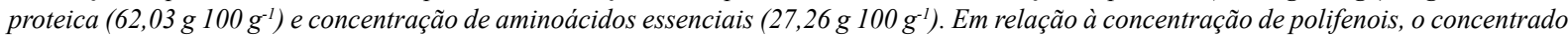

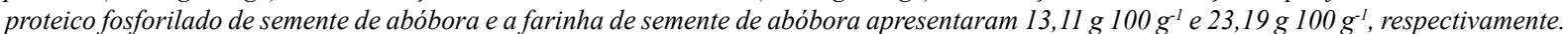
A adequação do modelo foi confirmada pela extração da proteína sobvalores ótimos. Estes resultados auxiliam na concepção do processo de extração ótimo da proteína de semente de abóbora.

Palavras-chave: aminoácidos, delinemamento composto central rotacional, digestibilidade in vitro, novo ingrediente.

\section{INTRODUCTION}

Food processing generates large quantities of new ingredients, which are under-used or discarded as agro-industrial waste (HELKAR et al., 2016). These wastes contain a high density of proteins, lipids and carbohydrates with potential for nutritional application (GUPTA, 2013). A strategy of bioremediation to reduce the environmental impact is to convert these materials in important food resources (EL-ADAWY, 2000).

In Brazil, agro-industrial produces a large variety of by-products and wastes, which have high nutritional potential. Pumpkins (Cucurbita moschata) are used for jam and candy preparations. Although, peels and seeds are usually discarded, the seeds are promising sources of protein. The protein content of pumpkin varies from $24.5 \%$ to $36 \%$ (WANG et al., 2001). They are also rich in polyunsaturated fatty acids (oleic and linoleic) and have high fiber content (ESUOSO et al., 1998; YOUNIS et al., 2000; KIM et al., 2012).

However, the anti-nutritional factors (ANF's) present in pumpkin seeds, as polyphenols, flavonoids and tannins limit their use in food formulations (DEL-VECHIO et al., 2005). In addition, the physical parameters, which are greatly influenced by the selection of raw materials (DRAGANOVIC et al., 2011). Current chemical treatments are driven by need to reduce ANF's of pumpkins (C. moschata). The technique of phosphorylation with sodium 
trimetaphosphate (STMP) can be applied to plant food sources for protein concentration and modification of amino acid profile (ELLINGER, 1972). Whereas research to improve the protein pumpkin seed profile are scarce, it is worth studying the optimum conditions of phosphorylation with STMP to protein extraction from pumpkin seeds and obtainment of protein concentrate.

The procedure of chemical phosphorylation can be further optimized by statistical response surface methodology (RSM). Its use provides the relevant information in the shortest time with the least number of experiments (MYERS \& MONTGOMERY, 2002). In addition to analyze the effects of the independent variables, this experimental methodology generates a mathematical model which describes the chemical or biochemical processes (BAS \& BOYACI, 2007) using various parameters such as $\mathrm{pH}$, temperature, solvent type, extraction time and solvent/meal ratio affect protein extractability (WANI et al., 2006).

In the present study, RSM was employed to optimize the protein extraction process from pumpkins seeds for maximum yield. The parameters investigated were $\mathrm{pH}$ and STMP concentration, aiming the nutritional characterization of the obtained product.

\section{MATERIALS AND METHODS}

The pumpkin seeds (Cucurbita moschata), courtesy of the company Ritter Alimentos S.A. from Cachoeirinha, RS, Brazil, were washed in distilled water to remove excess pulp, dried by hot-air drying at $45{ }^{\circ} \mathrm{C}$ to achieve a final water content of less than $10 \%$. After dehydration, seeds were grounded (particles $<1 \mathrm{~mm}$ ) in a cooled micro-mill (MA-630, Marconi $\left.^{\circledR}\right)$. The oil sample was extracted with Hexane (P.A. FMaia, Brazil) in the ratio 2:1 (hexane: sample) in three sequential washes. Finally, supernatant was discarded and precipitate resulted in pumpkin seed meal used to obtain the protein concentrates.

Extraction of protein concentrates was performed according to SMITH et al. (1946) with modifications. Phosphorylation was performed following the method of YAMADA et al. (2003). The procedure of protein concentration and phosphorylation is shown in figure 1. STMP was added to the pumpkin seed meal (PSM) according to the statistical design and the mixture was suspended in ten parts of distilled water. The solution was processed for three minutes in a blender (model LIQ789, Cadence, Brazil) and sieved in a 140 $\mu \mathrm{m}$ mesh. The fraction retained on the sieve was suspended following in distilled water at a ratio of
$1: 10$. This procedure was repeated until a ratio of 1:30 (PSM): distilled water was obtained at the end of processing. The three aqueous fractions were combined to obtain a single sample, $\mathrm{NaOH} 1 \mathrm{M}$ was added until $\mathrm{pH} 9.5$ to obtain solubilized protein.

The solution was allowed to stand for $30 \mathrm{~min}$ at room temperature and the $\mathrm{pH}$ was adjusted with $\mathrm{H}_{3} \mathrm{PO}_{4}$ (extra pure, 85\%) according to the statistical design. The solution was conditioned overnight at $8{ }^{\circ} \mathrm{C}$ to settle dispersed protein fraction, after the supernatant was discarded and the concentrated protein fraction was dried in an oven with air circulation at $50{ }^{\circ} \mathrm{C}$ (approximately $24 \mathrm{~h}$ ).

The protein concentration results were analyzed using the software Statistica ${ }^{\circledR} 7.0$ (Statsoft Inc., Tulsa, OK, USA), with a 95\% significance. The effects for sodium trimetaphosphate (STMP) concentration $(1.88-6.12 \% \mathrm{v} / \mathrm{w})$ and $\mathrm{pH}-$ phosphoric acid $-\mathrm{H}_{3} \mathrm{PO}_{4}(2.67-6.05)$ in yield of protein extraction and crude protein content from the phosphorylation were assessed by central composite rotational design (CCRD) with 8 runs and 3 central points.

The yield of the samples was calculated by the mass ( $\mathrm{g}$ ) of pumpkin seed meal used and the mass $(\mathrm{g})$ generated after the concentration procedure and chemical modification of the protein using the formula: $\mathrm{Y}(\%)=$ initial product weight $(\mathrm{g}) \times$ protein concentrate weight $(\mathrm{g}) / 100$, where $\mathrm{Y}$ represents the yield of the protein concentrate.

The crude protein was analyzed by determining total nitrogen by the micro Kjeldahl method using a conversion factor of $6.25(\mathrm{~N} \times 6.25)$, according to methodology n. 920.87 - AOAC (2000).

The protein concentrate obtained at $\mathrm{pH}$ 4.5 and 4\% STMP concentration was compared to pumpkin seed meal (raw material for obtaining the protein concentrate) for nutrients contents, amino acid composition, anti-nutritional factors, functional properties and in vitro protein digestibility.

Dry matter (DM), ash and crude protein (determination of nitrogen by the micro Kjeldahl method - N x 6.25, number 920.87) were determined according to the methodologies described by AOAC (2000). Residual fat was extracted and quantified by the cold extraction method (BLIGH \& DYER, 1959). The amount of neutral detergent fiber (NDF) was measured according to VAN SOEST et al. (1991).

For calcium and phosphorus analysis digestion was performed with concentrated $\mathrm{H}_{2} \mathrm{SO}_{4}$ plus the catalytic mixture of copper sulfate and potassium sulfate $\left(375{ }^{\circ} \mathrm{C}\right.$ for $\left.4.5 \mathrm{~h}\right)$. The reading was held in atomic absorption spectrophotometry for calcium and in the area of the visible for phosphorus 


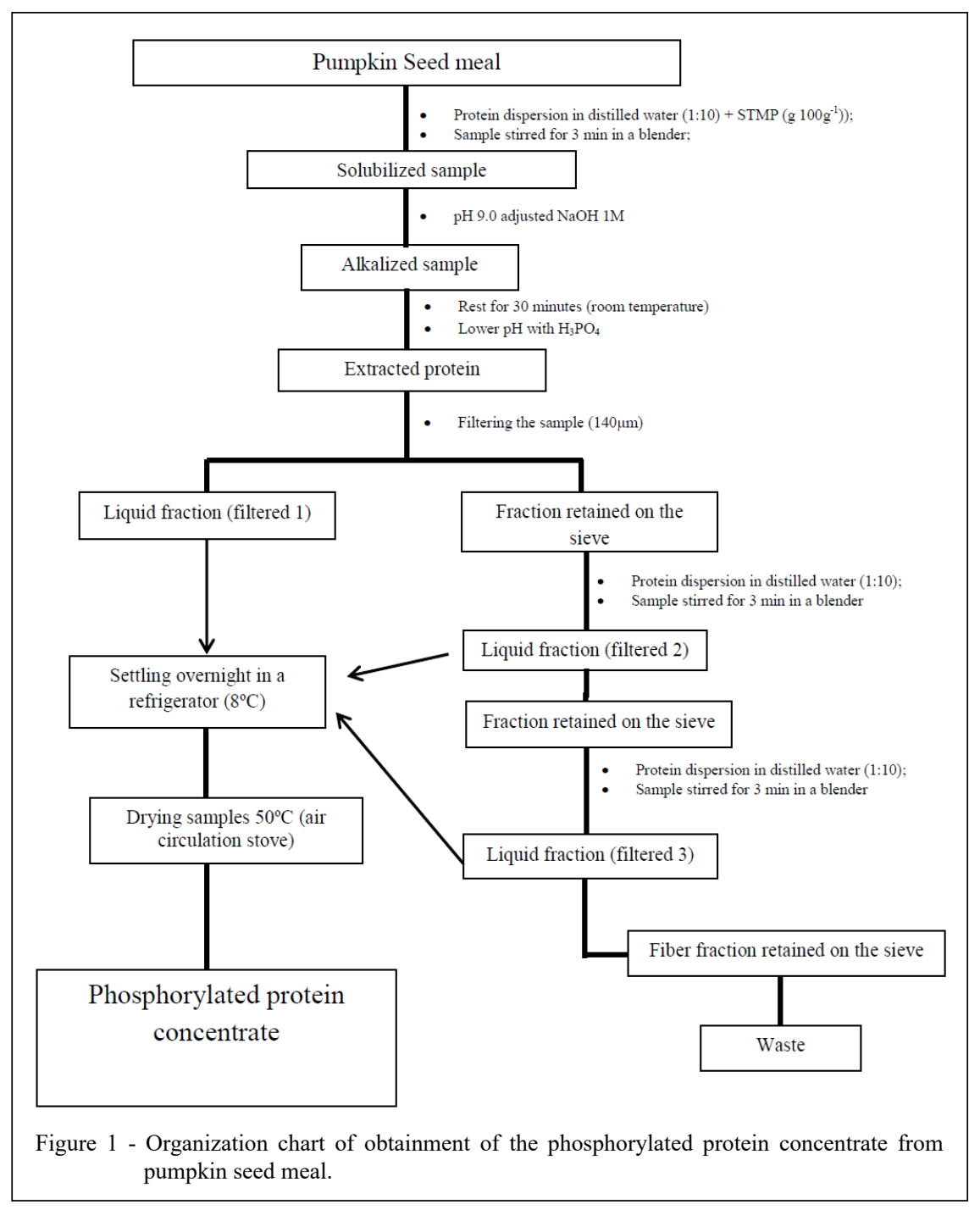

(colorimetric reaction of ammonium molybdate with phosphorus in the presence of reducing agent, using $\mathrm{K}_{2} \mathrm{HPO}_{4}$ as a standard (BAGINSKI et al., 1982).

The water holding capacity (WHC) and oil holding capacity (OHC) of the samples were determined as described by McCONELL et al. (1974). Samples were hydrated in distilled water (for WHC) or soy oil (for OHC). After equilibrium (24h) and centrifugation $(1,300 \times g$ for $20 \mathrm{~min})$, excess supernatant was discarded. Results were expressed as amount of water or oil by the sample $\left(\mathrm{g} \mathrm{g}^{-1}\right)$.

Polyphenol content was measured by the Folin-Ciocalteu method described by CHANDRA \& MEJIA (2004). The data were expressed accordance with the acid gallic equivalent (GAE) presents in a mass of crude extract $\left(\mathrm{mg} \mathrm{g}^{-1}\right)$. The content of flavonoids was determined by the reaction with aluminum chloride using the method described by WOISKY \& SALATINO (1998). The data were calculated based on the calibration rutin curve and expressed in rutin equivalents (RE) $\mathrm{mg} \mathrm{g}^{-1}$ of extract.

The determination of condensed tannins was performed by the MORRISSON et al. (1995) method, which used vanillin as reagent. The absorbance of $500 \mathrm{~nm}$ was measured by spectrophotometer. Data were calculated based on the calibration catechin curve and expressed in catechin equivalents (CE) $\mathrm{mg} \mathrm{g}^{-1}$ of each one of the fractions.

In vitro digestibility of protein assay was performed as proposed by MAURON (1973), with modifications proposed by DIAS et al. (2010). The method is based on the digestion of the sample by the 
enzymes pepsin (1:10.000, Nuclear) and pancreatin (Sigma). The digestibility results from the relationship between the total nitrogen in the sample, the digested nitrogen, and the nitrogen produced by the auto digestion of the enzymes and the soluble nitrogen originally in the ingredient. For this reaction $10 \mathrm{~mL}$ of $\mathrm{HCl} 0.1 \mathrm{~N}$ and $4 \mathrm{mg}$ of pepsin (dilution in $\mathrm{HCl} 0.1$ $\mathrm{N})$ were added to the defatted sample $(100 \mathrm{mg})$ at the ratio $10: 1(\mathrm{w} / \mathrm{v})$. Samples were kept in a water bath at $37{ }^{\circ} \mathrm{C}$ under constant stirring for $1 \mathrm{~h}$. The $\mathrm{pH}$ was adjusted at $7.0(\mathrm{NaOH} 0.4 \mathrm{~N}), 20 \mathrm{mg}$ of pancreatin (diluted in sodium phosphate buffer $0.1 \mathrm{M} \mathrm{pH} 8.5$ at the ratio1: $10(\mathrm{w} / \mathrm{v})$ were added to each sample. Samples were kept at $37{ }^{\circ} \mathrm{C}$ and stirred for $3 \mathrm{~h}$. The reaction was stopped with trichloroacetic acid (final concentration 5\%). A $2 \mathrm{~mL}$ portion was removed for the determination of total nitrogen in the sample and the remaining fraction was centrifuged $(10,000 \mathrm{rpm}$, $10 \mathrm{~min}$ ) and digested nitrogen was analyzed. For each sample, a blank was accomplished using water instead of the enzyme, in order to verify the soluble nitrogen in the sample and for nitrogen content from enzymatic auto-digestion are considered. The nitrogen content of each fraction is determined by the Micro Kjeldahl method (AOAC, 2000). Casein was adopted as the standard (Synth, Brazil, 90\% purity) to compare sample digestibility.

The amino acid profile was determined by high performance liquid chromatography (HPLC), with hydrolysis of samples in $\mathrm{HCl} 6 \mathrm{M}$ solution. The released amino acids were derivatized with phenylisothiocyanate (PITC) and separated with reverse phase column $\mathrm{C} 18$ (Pico-Tag - 3.9x300 mm) and UV detection at $254 \mathrm{~nm}$, by the methodology proposed by WHITE et al. (1986).

For the CCRD, a second order polynomial equation was used to adjust the data in table 1 , according to the model:

$Y_{i}=a_{0}+a_{1} X_{1}+a_{2} X_{2}+a_{11} X_{1}^{2}+a_{22} X_{2}^{2}+a_{12} X_{1} X_{2}$

Where $\mathrm{Y}_{i}(i=1-2)$ is the predicted response for the values of crude protein $(\mathrm{CP} \%)$ and yield $(\mathrm{Y} \%)$ of the protein concentrate. The term $\alpha_{0}$ is the response obtained in the design central point, $\alpha_{1}$ and $\alpha_{2}$ are the linear terms, $\alpha_{12}$ is the interaction of the effects and $\alpha_{11}$ and $\alpha_{22}$ are the quadratic effects. The experimental and predicted responses were compared. The results were analyzed by analysis of variance (ANOVA) to validate the statistical model. Graphical and regression analysis were performed using the statistical software Statistica $^{\circledR} 7.0$ (Statsoft Inc., Tulsa, OK, USA) with a significance level of $95 \%(\mathrm{P}<0.05)$.

Nutritional, ANF's, functional analysis data and in vitro digestibility protein were subjected to one way ANOVA and $\mathrm{F}$ test for comparison were run at the $5 \%$ probability level by Tukey's test. The mathematical model is described: $Y_{i j}=m+t_{i j}+e_{i j}$, where $Y_{i j}$ represents observed value of variable $Y$ in the experimental unit that received treatment $i$ in the repetition $\mathrm{j} ; \mathrm{m}=$ constant $\mathrm{t}_{\mathrm{i}}=$ effect of the treatment $\mathrm{i}$; $\mathrm{e}_{\mathrm{ij}}=$ experimental error.

\section{RESULTS}

The highest yield of protein extraction and the better crude protein content, considering 11 runs

Table 1 - Central composite rotational design (CCRD) and responses of yield and crude protein content obtained in different combinations of sodium trimetaphosphate (STMP) and $\mathrm{pH}$.

\begin{tabular}{lcccc}
\hline Run & STMP $\left({\left.\mathrm{g} 100 \mathrm{~g}^{-1}\right)^{1}}^{1}\right.$ & $\mathrm{pH}$ & $\mathrm{Y}(\%)^{2}$ & $\mathrm{CP}(\%)^{3}$ \\
\hline 1 & $2.50(-1)$ & $3.20(-1)$ & 44.33 & 60.04 \\
2 & $5.50(1)$ & $3.20(-1)$ & 40.80 & 65.28 \\
3 & $2.50(-1)$ & $5.60(1)$ & 36.66 & 64.59 \\
4 & $5.50(1)$ & $5.60(1)$ & 42.54 & 59.23 \\
5 & $4.00(0)$ & $4.50(0)$ & 49.34 & 62.08 \\
6 & $4.00(0)$ & $4.50(0)$ & 50.04 & 62.06 \\
7 & $4.00(0)$ & $4.50(0)$ & 49.68 & 62.56 \\
8 & $1.88(-1.41)$ & $4.50(0)$ & 42.0 & 64.14 \\
9 & $6.12(1.41)$ & $4.50(0)$ & 47.36 & 59.98 \\
10 & $4.00(0)$ & $2.67(-1.41)$ & 45.76 & 62.19 \\
11 & $4.00(0)$ & $6.05(1.41)$ & 37.76 & 64.81 \\
\hline
\end{tabular}

${ }^{1} \mathrm{STMP}$ - Sodium TrimetaPhosphate; ${ }^{2}$ Yield; ${ }^{3} \mathrm{CP}$ - Crude protein. 
of the CCRD, were $50.04 \%$ and $65.28 \%$, respectively (Table 1). Linear effects for STMP was statistically significant, but negative, with $90 \%$ of significance $(\mathrm{P}<0.1)$, while the linear effect for $\mathrm{pH}$ and the interaction effect between STMP and $\mathrm{pH}$ was not statistically significant (Figure 2a).

The highest protein extraction yield (50.04 $\mathrm{g} 100 \mathrm{~g}^{-1}$ ) was obtained in experiment 6 , for STMP

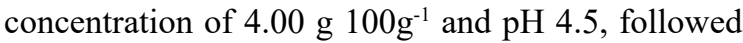

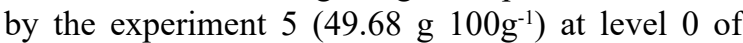
the CCRD for STMP concentration and $\mathrm{pH}$. The quadratic effects for STMP concentration and $\mathrm{pH}$ were statistically significant $(\mathrm{P}<0.05)$, all of them negatives. The negative effects of quadratic terms are related to a presence of maximum point for each variable within the studied range. To identify these maximum points an empirical model was generated considering the significant terms plus the interaction of STMP concentration and $\mathrm{pH}$, which is presented in the Equation below:

$Y \%=49.67-3.03 \cdot P^{2}-4.49 \cdot S^{2}+1.24 \cdot P-2.15 . S+2.32 P \cdot S$

Where $\mathrm{Y} \%$ is the yield of extraction protein $\left(\mathrm{g} 100 \mathrm{~g}^{-1}\right)$ obtained by the phosphorylation from pumpkin seeds, $\mathrm{P}$, and $\mathrm{S}$ are the coded variables to $\mathrm{pH}$ and STMP concentration, respectively. This model was validated by analysis of variance (ANOVA) and the determination coefficient $\left(\mathrm{R}^{2}\right)$ was 0.9242 . The applicability of the second order polynomial equation is presented in figure 2, where it is seen that maximum yield of hydrolysis can be obtained around of central point of each variable.

Only linear effects of available variables were statistically significant (Figure 3). The interaction between $\mathrm{pH}$ and STMP concentration was statistically significant, but showed a negative effect on crude protein content. In the same way that protein extraction yield obtained from phosphorylation of pumpkin seeds, was generated an empirical model from data of table 1, but this model was not validated by analysis of variance (ANOVA) and, for this reason, it was not presented here.

The use of phosphorylation produced a new ingredient with $53.5 \%$ higher protein content than its original raw material and equivalent to the reference standard of animal-based protein sources (Table 2). The total fat content was lower $(\mathrm{P}<0.05)$ for the pumpkin seed meal $(2.9 \%)$ when compared to PPCPS (about 9\%). The fiber (NDF) content was $33.79 \%$ lower for PPCPS than its original raw material (PSM). The levels of phosphorus $(\mathrm{P}<0.05)$ were higher for PPCPS. The increase in the ash content $(\mathrm{P}<0.05)$ in PPCPS was observed.

The high WHC $(\mathrm{P}<0.05)$ of PSM were attributed to their higher content of polar amino acids when compared to PPCPS. The OHC was higher for PSM than PPCPS $(\mathrm{P}<0.05)$, with similar behavior to the hydration capacity (Table 2 ).

The phosphorylation procedure is ineffective in reducing flavonoids. However, it caused a decrease $(\mathrm{P}<0.05)$ of $56.53 \%$ in total polyphenol content for PPCPS $\left(13.11 \mathrm{mg} \mathrm{g}^{-1}\right)$ when compared to the PSM (23.19 $\left.\mathrm{mg} \mathrm{g}^{-1}\right)$ (Table 2). In this study, condensed tannins compounds were not detected in samples.

PSM showed low protein digestibility in vitro (Table 2). The PPCPS showed higher content of essential amino acids $(\mathrm{P}<0.05)$ than PSM (Table 3).
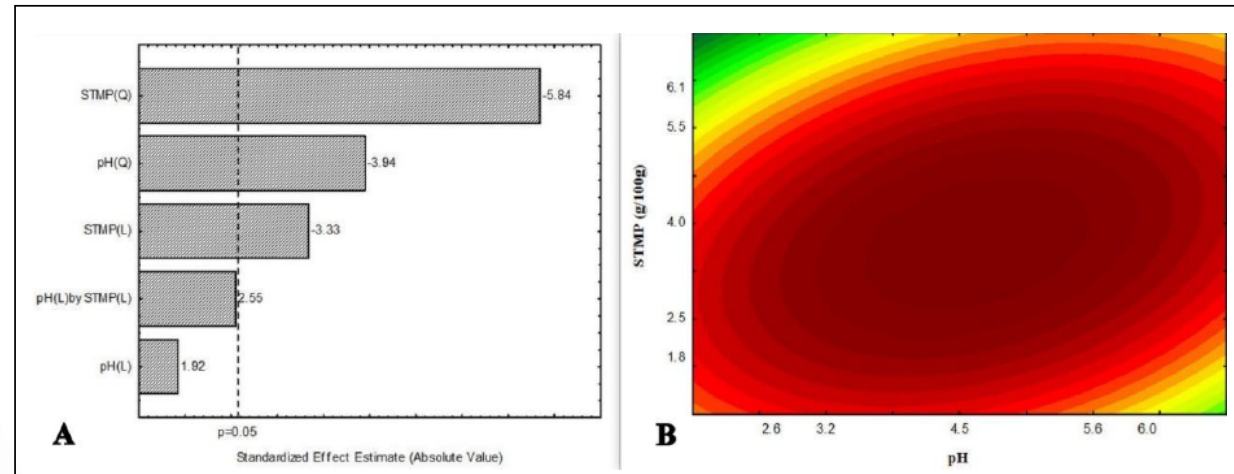

Figure 2 - Pareto chart (A) and contour plot (B) expressing the effects of variables to yield of protein extraction by phosphorylation of pumpkin seed; (Q): quadratic; (L): linear. STMP: Sodium

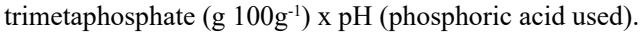




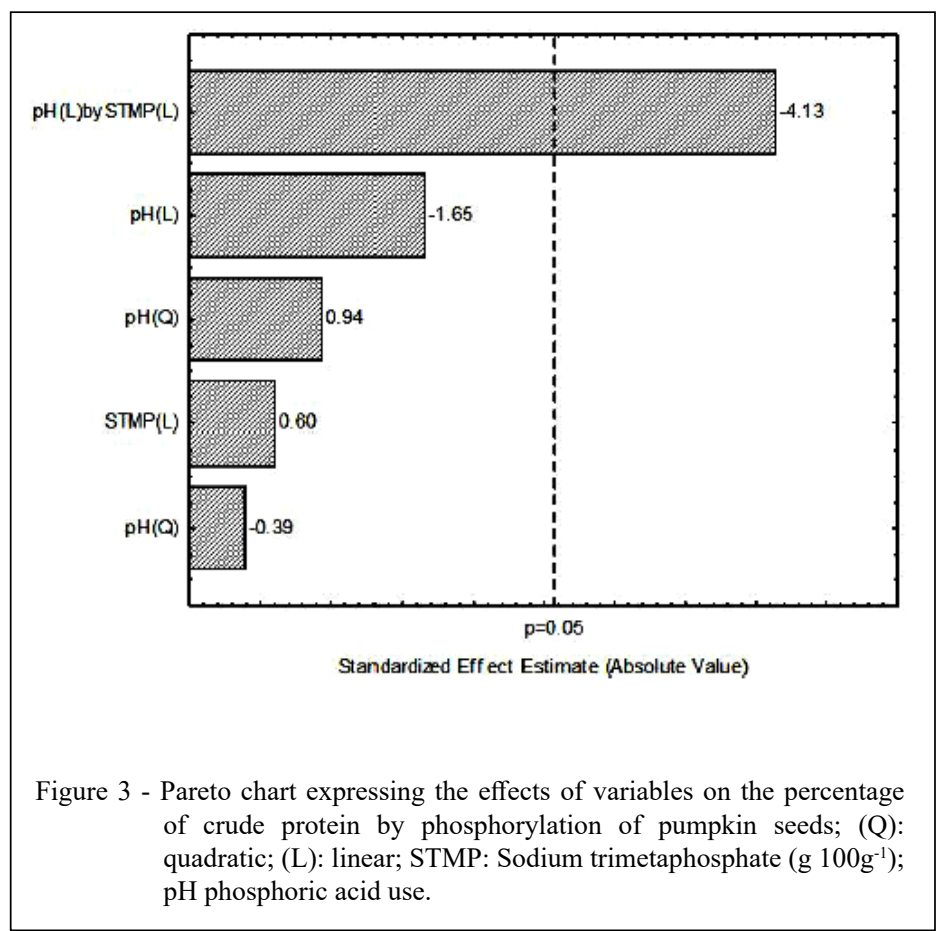

\section{DISCUSSION}

Protein pumpkin seed was extracted following 11 combinations of two independent variables ( $\mathrm{pH}$ and STMP content). Both $\mathrm{pH}$ and STMP content had a quadratic effect on protein extraction (Figure 2b). Considering all the response, it is evident that $\mathrm{pH}$ had a significant effect on protein yield. This statement is in accordance with the results obtained in runs 10 and 11, which the variation of $\mathrm{pH}$ (2.67 to 6.05 ) results in a decrease of protein yield of 45.76 to $37.76 \%$, respectively MIEDZIANKA

Table 2 - Composition of pumpkin seed meal (PSM) and phosphorylated protein concentrate from pumpkin seed meal (PPCPS).

\begin{tabular}{|c|c|c|}
\hline Nutrient & $\operatorname{PSM}^{1}$ & $\mathrm{PPCPS}^{2}$ \\
\hline & \multicolumn{2}{|c|}{ 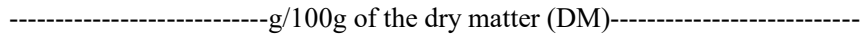 } \\
\hline Crude protein & $44.48 \pm 1.34^{\mathrm{b}}$ & $67.48 \pm 2.75^{\mathrm{a}}$ \\
\hline Lipid & $3.06 \pm 0.06^{\mathrm{b}}$ & $10.30 \pm 0.29^{\mathrm{a}}$ \\
\hline $\mathrm{NDF}$ & $37.17 \pm 0.91^{\mathrm{a}}$ & $12.53 \pm 1.88^{\mathrm{b}}$ \\
\hline Calcium & $0.32 \pm 0.09^{\mathrm{c}}$ & $0.67 \pm 0.08^{\mathrm{b}}$ \\
\hline Phosphorus & $1.00 \pm 0.13^{\mathrm{c}}$ & $7.33 \pm 0.40^{\mathrm{a}}$ \\
\hline Ash & $9.92 \pm 1.76^{\mathrm{c}}$ & $27.78 \pm 2.26^{\mathrm{a}}$ \\
\hline Polyphenols & $23.19 \pm 0.46^{\mathrm{a}}$ & $13.11 \pm 0.26^{\mathrm{b}}$ \\
\hline Flavonoids & $13.55 \pm 0.25^{\mathrm{a}}$ & $12.39 \pm 0.25^{\mathrm{a}}$ \\
\hline WHC (g water g product ${ }^{-1}$ ) & $1.99 \pm 0.17^{\mathrm{b}}$ & $1.68 \pm 0.05^{\mathrm{c}}$ \\
\hline OHC (g oil g product $\left.{ }^{-1}\right)$ & $1.60 \pm 0.01^{\mathrm{a}}$ & $0.72 \pm 0.01^{\mathrm{b}}$ \\
\hline In vitro protein digestibility ${ }^{3}$ & $23.06 \pm 6.85^{b}$ & $62.03 \pm 1.74^{\mathrm{a}}$ \\
\hline
\end{tabular}

Mean values followed by different letters in the row were considered significantly different using the Tukey's test (P<0.05). ${ }^{1} \mathrm{PSM}-$ Pumpkin Seed Meal; ${ }^{2}$ PPCPS - Phosphorylated Protein Concentrate of Pumpkin Seed meal; ${ }^{3}$ Casein was used as standard protein: digestibility of $769.2 \mathrm{~g} \mathrm{~kg}^{-1}$. 
Table 3 - Total amino acid composition of meal (PSM) and phosphorylated protein concentrate from pumpkin seed (PPCPS).

\begin{tabular}{|c|c|c|}
\hline Amino acids & $\mathrm{PSM}^{1}$ & $\mathrm{PPCPS}^{2}$ \\
\hline & \multicolumn{2}{|c|}{ 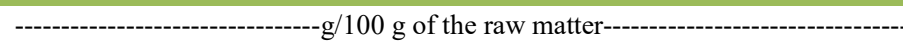 } \\
\hline Isoleucine & 1.17 & 2.00 \\
\hline Leucine & 2.07 & 3.67 \\
\hline Lysine & 1.72 & 1.72 \\
\hline Methionine & 0.64 & 1.12 \\
\hline Cystine & 0.36 & 0.51 \\
\hline Tyrosine & 2.21 & 1.99 \\
\hline Phenylalanine & 1.51 & 2.78 \\
\hline Threonine & 0.85 & 1.48 \\
\hline Valine & 1.55 & 2.65 \\
\hline Tryptophan & NA & NA \\
\hline Histidine & 0.82 & 1.10 \\
\hline Arginine & 5.02 & 8.24 \\
\hline Total essential AA & 17.92 & 27.26 \\
\hline Asparagine & 3.97 & 5.22 \\
\hline Glutamine & 5.97 & 9.50 \\
\hline Serine & 1.85 & 2.85 \\
\hline Proline & 1.17 & 2.98 \\
\hline Glycine & 2.98 & 4.75 \\
\hline Histidine & 0.82 & 2.10 \\
\hline Total & 34.68 & 54.56 \\
\hline
\end{tabular}

Mean values followed by different letters in the row were considered significantly different using the Tukey's test (P<0.05). ${ }^{1} \mathrm{PSM}$ Pumpkin Seed Meal; ${ }^{2}$ PPCPS - Phosphorylated Protein Concentrate of Pumpkin Seed meal.

\& PEKSA (2013) reported that a decrease of total protein content $(96.32 \%$ to $88.87 \%)$ at $\mathrm{pH} 5.2$ and 10.5 , respectively, may be attributed to introduction of phosphate groups onto polypeptide chains and the solubilization under alkaline conditions.

Conversely, in our study the increase of $\mathrm{pH}$ resulted in a lower protein yield. In the same way, a study conducted by MIEDZIANKA \& PEKSA (2013) showed that phosphorylation under alkaline condition $(\mathrm{pH} 10.5)$ was characterized by the lowest solubility of protein which can be attributed to polymerization of proteins. In despite of a previous study (GIEC et al., 1989) where the degree of protein phosphorylation studied range increases with increase of $\mathrm{pH}$ and STMP, in our study the $\mathrm{pH}$ of 4.5 stimulates the protein concentration and diminishes the occurrence of anti-nutritional compounds. The protein concentrates obtained demonstrate quite high contents of crude protein. It can be seen that the phosphorylation procedure increases extractability and facilities separation of protein from nucleic acids of yeast (GIEC et al., 1989).

Moreover, in our study the phosphorylation increased content of arginine, tyrosine, phenylalanine and valine, without decreasing the lysine content. This occurred because the N-P binding between lysine and the phosphate group in phosphorylation is acid labile. However, under conditions that prevailing in the stomach during the digestion process, the N-phosphorylated proteins are dephosphorylated and lysyl residues will be regenerated, without causing negative impact on the digestibility of lysine and other amino acids (DAMODARAN \& PARKIN, 2019).

The amino acid composition of plant-based ingredients may vary depending on cultivars, culture treatments and industrial processing (LEDOUX et al., 1999; TAVERNARI et al., 2010). However, regardless of the variations, usually these sources are deficient in lysine and methionine (TUSCHE et al., 2011). The increase of these amino acids by phosphorylation showed that this technique is effective for concentration and increase quality of protein.

Phenolic compounds are anti-nutritional compounds that causing negative effects in color, flavor and nutritional quality of ingredients (SILVA \& SILVA, 1999). The fiber reduction resulting 
of protein processing concentration promotes a decrease in the content of phenolic compounds, improving the nutritional and sensory characteristics of the ingredient. The low in vitro digestibility of proteins in PSM is associated with high fiber content (TORSTENSEN et al., 2008). The excess of fiber can be considered a negative point for digestibility of nutrients. However, raw vegetable ingredients, such as pumpkin seed meal, consist in great sources of fiber, protein and lipids, and can or cannot have success for animal nutrition.

The ANF's have different characteristics related to chemical classification and conformation. This results in different forms to inactivate them, as well as synergy and / or antagonism of nutrients (NRC, 2011). In the PSM, higher levels of some antinutritional compounds, such as polyphenols, flavonoid, and fiber were observed (Table 2). However, the methodology applied for obtaining the protein concentrate showed to be efficient for reducing some of them. At the beginning, the sample is homogenized in an aqueous medium and the antinutritional compounds can be removed, as well as polyphenols and fiber. After the sample dispersion in water, the separation of protein (liquid medium) from the fiber portion (retained at the sieve) should be occurred, and the protein in aqueous medium is solubilized in alkaline medium $(\mathrm{pH} 9-10)$. In this point, the anti-nutritional compounds can be also removed, since the alkaline treatment is considered as an efficient method for reducing some of compounds (OCHANDA et al., 2010).

The reduction of fiber in pumpkin seeds by phosphorylation resulted in increased protein digestibility for PPCPS. Second MATHEIS et al. (1983), these results can be attributed to partial hydrolysis of the protein and amino acids caused by the chemical phosphorylation procedure.

The phosphorylation results showed a low water holding capacity (WHC). This behavior occurs because proteins exhibit the least hydration at their isoelectric $\mathrm{pH}$, where enhanced proteinprotein interactions results in minimal interaction with water (DAMODARAN \& PARKIN, 2019). The study carried by DENCH et al. (1981) reported that absorption of fat depending on the number of protein hydrophobic groups exposed.

Ingredients with lower WHC require less water during the extrusion feed procedure. The lower WHC and OHC of the obtained PPCPS when compared to PSM may form pellets which require less water for extrusion, favoring energy consumption and low generation of residues (DRAGANOVIC et al., 2014).
The pumpkin seeds phosphorylation resulted in a concentrate product with low content of ANF's and fiber, high protein digestibility and concentration of essential amino acids. The presence of ANF's in protein concentrates may decrease the enzymatic hydrolysis of these proteins (DAMODARAN \& PARKIN, 2010).

\section{CONCLUSION}

In conclusion, response surface methodology (RSM) proved to be a useful tool establishing optimum conditions for extracting pumpkin seed protein. The second order model developed for protein yield exhibited a significant value for lack of fit and high value for the coefficient of determination. Optimum extraction of pumpkin seed proteins can be achieved by STMP concentration of $4.00 \%$ at $\mathrm{pH} 4.5$. These conditions resulted in protein yield of $50.04 \mathrm{~g}$ of soluble protein from extract $100 \mathrm{~g}^{-1}$ pumpkin seed. Isolated product has a protein content of $67.48 \mathrm{~g} 100 \mathrm{~g}^{-1} \mathrm{DM}$. The optimum conditions can be used to produce protein concentrate from pumpkin seed.

\section{ACKNOWLEDGEMENTS}

The research was financed in part by the Coordenação de Aperfeiçoamento de Pessoal de Nível Superior (CAPES), Brasil - Finance code 001.

\section{DECLARATION OF CONFLICT OF INTERESTS}

The authors declare no conflict of interest. The founding sponsors had no role in the design of the study; in the collection, analyses, or interpretation of data; in the writing of the manuscript, and in the decision to publish the results.

\section{AUTHORS' CONTRIBUTIONS}

All authors contributed equally for the conception and writing of the manuscript. All authors critically revised the manuscript and approved of the final version.

\section{REFERENCES}

AOAC. Association of Analytical Chemists. Official Methods of Analysis of AOAC International, Gaisthersburg, 17 ed., 2000, v.I e II.

BAGINSKI, E.S. et al. Phosphate, inorganic. In: BAGINSKI, E. S. (Ed.). Selected Methods of Clinical Chemistry. American Association of Clinical Chemistry, p.313-316, 1982.

BAS, D.B., BOYACI, I.H. Modeling and optimization I: Usability of response surface methodology. Journal of Food Engineering, v.78, p.836-845, 2007. Available from: <https://doi.org/10.1016/j. jfoodeng.2005.11.024>. Accessed: Oct. 08, 2016. doi: 10.1016/j. jfoodeng.2005.11.024. 
BLIGH, E.G., DYER, W.J. A rapid method of total lipid extraction and purification. Canadian Journal of Biochemistry and Physiology, v.37, n.8, p.911-917, 1959. Available from: $<$ https://doi.org/10.1139/o59-099>. Accessed: Jul. 20, 2016. doi: 10.1139/059-099.

CHANDRA, S., MEJIAE.G. Polyphenolic compounds, antioxidant capacity, and quinone reductase activity of an aqueous extract of Ardisia compressa in comparison to mate (Ilex paraguariensis) and green (Camellia sinensis) teas. Journal of Agriculture and Food Chemistry, v.52, p.3583-3589, 2004. Available from: <http:// www.ncbi.nlm.nih.gov/pubmed/15161234>. Accessed: Nov. 05, 2016. doi: $10.1021 / \mathrm{j} f 0352632$.

DAMODARAN, S., PARKIN, K.L. Química de alimentos de Fennema. 5. ed. Porto Alegre: Artmed, 2019. 1112p.

DEL-VECHIO, G. et al. 2005. Effect of the thermal processing on pumpkin seeds (Cucurbita spp.) on the levels of antinutritionales factors and/or toxics. Ciência e Agrotecnologia, v.29, p.369376, 2005. Available from: <http://dx.doi.org/10.1590/S141370542005000200014>. Accessed: Nov. 05, 2016. doi: 10.1590 S1413-70542005000200014

DENCH, J.E. et al. Selected functional properties of sesame (Sesame indicum $L$ ) flour and two protein isolates. Journal of the Science of Food and Agriculture, v.32, p.557-564, 1981. Available from: <http://onlinelibrary.wiley.com/doi/10.1002 jsfa.2740320606/full>. Accessed: Jul. 20, 2016. doi: 10.1002/ jsfa.2740320606

DIAS, D.R. et al. In vitro protein digestibility of enzymatically pre-treated bean (Phaseolus vulgaris L.) flour using commercial protease and Bacillus sp. protease. Ciência e Tecnologia de Alimentos, v.30, p.94-99, 2010. Available from: <http://dx.doi. org/10.1590/S0101-20612010005000010>. Accessed: Nov. 15, 2016. doi: 10.1590/S0101-20612010005000010.

DRAGANOVIC, V. et al. Lupine and rapeseed protein concentrate in fish feed: A comparative assessment of the techno-functional properties using a shear cell device and an extruder. Journal of Food Engineering, v.126, p.178-189, 2014. Available from: $<$ https://doi.org/10.1016/j.jfoodeng.2013.11.013>. Accessed: Jun. 03, 2017. doi: 10.1016/j.jfoodeng.2013.11.013.

DRAGANOVIC, V. et al. Assessment of the effects of fish meal, wheat gluten, soy protein concentrate and feed moisture on extruder system parameters and the technical quality of fish feed. Animal Feed Science and Technology, v.165, p.238-250, 2011. Available from: $<$ https://doi.org/10.1016/j.anifeedsci.2011.03.004>. Accessed: Nov. 26, 2016. doi: 10.1016/j.anifeedsci.2011.03.004.

ESUOSO, K. et al. Chemical composition and potential of some underutilized tropical biomass. I: fluted pumpkin (Telfairia occidentalis). Food Chemistry, v.61, p.487-492, 1998. Available from: <https://doi.org/10.1016/S0308-8146(97)00096-4>. Accessed: Sep. 14, 2016. doi: 10.1016/S0308-8146(97)00096-4.

GIEC, A. et al. A protein isolate for food by phosphorylation of yeast homogenate. Food Chemistry, v.31, p.279-288, 1989. Available from: <https://doi.org/10.1016/0308-8146(89)900691>. Accessed: Jul. 20, 2016. doi: 10.1016/0308-8146(89)90069-1.

GUPTA, V.K., TUOHY, M.G. eds, Biofuel Technologies, Recent Developments. Ed. Springer, 2013, 534p.
HELKAR, B.P., SAHOO, A.K., PATIL, N.J. Review: Food Industry By-Products used as a Functional Food Ingredients. International Journal of Waste Resources, v.6, n.3, p.1-6, 2016. Available from: <http://doi:10.4172/2252-5211.1000248>. Accessed: Apr. 30, 2019. doi: 10.4172/2252-5211.1000248.

KIM, M.Y. et al. Comparison of the chemical compositions and nutritive values of various pumpkin (Cucurbitaceae) species and parts. Nutrition Research and Practice, v.6, n.1, p.2127, 2012. Available from: <https://www.ncbi.nlm.nih.gov/pmc/ articles/PMC3296918/>. Accessed: Jun. 15, 2016. doi: 10.4162/ nrp.2012.6.1.21.

LEDOUX, D.R. et al. Effects of feeding crambe meal upon intake, gain, health, and meat quality of broiler chicks. Animal Feed Science and Technology, v.76, p.227-240, 1999. Available from: $<$ https://doi.org/10.1016/S0377-8401(98)00225-9>. Accessed: Jul. 02, 2016. doi: 10.1016/S0377-8401(98)00225-9.

MATHEIS, G. et al. Phosphorylation of casein and lysozyme by phosphorus oxychloride. Journal of Agricultural and Food Chemistry, v.31, p.379-387, 1983. Available from: <http://pubs. acs.org/doi/abs/10.1021/jf00116a049>. Accessed: Mar. 17, 2016. doi: $10.1021 /$ jf00116a049

MAURON, J. The analysis of food proteins: amino acid composition and nutritive value. In: PORTER, J.W.G. \& ROLLS, B.A. eds., Proteins in human nutrition, London, Academic Press, 1973, p.139-154.

MCCONELL, A.A. et al. Physical characteristics of vegetable foodstuffs that could influence bowel function. Journal of the Science of Food and Agriculture, v.25, p.1457-1464, 1974. Available from: <http://dx.doi.org/10.1002/jsfa.2740251205>. Accessed: Jun. 24, 2016. doi: 10.1002/jsfa.2740251205.

MIEDZIANKA, J., PĘKSA, A. Effect of pH on phosphorylation of potato protein isolate. Food Chemistry, v.138, p.23212326, 2013. Available from: <https://doi.org/10.1016/j. foodchem.2012.12.028>. Accessed: Mar. 30, 2016. doi: 10.1016/j. foodchem.2012.12.028

MORRISSON, I.M. et al. Determination of lignin and tannin contents of cowpea seed coats. Annals of Botany, v.76, p.287-290, 1995. Available from: <https://doi.org/10.1006/anbo.1995.1097>. Acessed: Aug. 24, 2016. doi: 10.1006/anbo.1995.1097.

MYERS, R.H., MONTGOMERY, D.C. Response Surface Methodology: Process and Product Optimization Using Designed Experiments. Wiley-Interscience: $2^{\text {nd }} \mathrm{Ed}, 2002$.

NATIONAL RESEARCH COUNCIL - NRC. Nutrient requirements of fish and shrimp. Washington, D.C.: National Academy Press, 2011. 360p.

OCHANDA S.O. et al. Effects of alkali treatment on tannins and phytates in red sorghum, white sorghum and pearl millet. Journal of Applied Biosciences, v.36, p.2409 - 2418, 2010.

SILVA, M.R., SILVA, M.A.A.P. Nutritional aspects of phytates and tannins. Revista de Nutrição, v.12, p.5-19, 1999. Available from: <http://dx.doi.org/10.1590/S141552731999000100002>. Accessed: Nov. 26, 2016. doi: 10.1590/ S1415-52731999000100002. 
SMITH, A.K., JOHNSON, V.L., BECKEL, A.C. Linseed proteins alkali dispersion and acid precipitation. Journal of Industrial and Engineering Chemistry, v.38, p.353-356, 1946.

TAVERNARI, F.C. et al. Nutritional and energetic evaluation of sunflower meal in broiler diets. Arquivo Brasileiro de Medicina Veterinária e Zootecnia, v.62, n.1, p.172-177, 2010. Available from: <http://dx.doi.org/10.1590/S0102-09352010000100023>. Accessed: Feb. 12, 2017. doi: 10.1590/S0102-09352010000100023.

TORSTENSEN, B.E. et al. Novel production of Atlantic salmon (Salmo salar) protein based on combined replacement of fish meal and fish oil with plant meal and vegetable oil blends. Aquaulture, v.285, p.193-200, 2011.

TUSCHE, K. et al. Evaluation of feed attractants in potato protein concentrate based diets for rainbow trout (Oncorhynchus mykiss). Aquaculture, v.321, p.54-60, 2011. Available from: <https:// doi.org/10.1016/j.aquaculture.2008.08.025>. Accessed: Nov. 12, 2016. doi: 10.1016/j.aquaculture.2008.08.025.

VAN SOEST, P.J. et al. Methods for dietary fiber, neutral detergent fiber, and nonstarch polysaccharides in relation to animal nutrition. Journal of Dairy Science, v.74, p.3583-3597, 1991. Available from: $<$ http://dx.doi.org/10.3168/jds.S0022-0302(91)78551-2>. Accessed: Nov. 14, 2016. doi: 10.3168/jds.S0022-0302(91)78551-2.

WANG, P., ZHAO, Q., WANG, R., CUI, S. The study on change of main nutrition during maturation process in seed pumpkin seed. Acta Horticulturae Sinica, 2001. Available from: $<$ http://en.cnki. com.cn/Article en/CJFDTOTAL-YYXB200101009.htm>. Accessed: Apr. 30, 2019.
WANI, A.A. et al. Effect of temperature, alkali concentration, mixing time and meal/solvent ratio on the extraction of watermelon seed proteins - a response surface. Biosystems Engineering, v.94, n.1, p.67-73, 2006. Available from: <https://doi.org/10.1016/j. biosystemseng.2006.02.004>. Accessed: Oct. 23, 2016. doi: 10.1016/j.biosystemseng.2006.02.004.

WHITE, J. et al. An evaluation of the Waters Pico-Tag system for the amino-acid-analysis of food materials. Journal of Automated Methods and Management in Chemistry, v.8, p.170-177, 1986. Available from: <https://www.ncbi.nlm.nih.gov/pmc/ articles/PMC2547673/>. Accessed: Feb. 15, 2016. doi: 10.1155/ S1463924686000330.

WOISKY, R.G., SALATINO, A. Analysis of propolis: some parameters and procedure for chemical quality control. Journal of Apicultural Research, v.37, p.99-105, 1998. Available from: $<$ http://dx.doi.org/10.1080/00218839.1998.11100961>. Accessed: Jan. 28, 2016. doi: 10.1080/00218839.1998.11100961.

YAMADA, E.A. et al. Composição centesimal e valor proteico de levedura residual da fermentação etanólica e de seus derivados. Revista de Nutrição, v.16, p.423-432, 2003. Available from: <http://dx.doi.org/10.1590/S141552732003000400006>. Accessed: Jun. 12, 2016. doi: 10.1590/ S1415-52732003000400006.

YOUNIS, Y.M. et al. African Cucurbita pepo L.: properties of seed and variability in fatty acid composition of seed oil. Phytochemistry, v.54, p.71-75, 2000. Available from: $<$ https://doi. org/10.1016/S0031-9422(99)00610-X>. Accessed: Oct. 16, 2016. doi: 10.1016/S0031-9422(99)00610-X. 